\title{
PENGGUNAAN SOSIAL MEDIA SEBAGAI BAHAN AJAR WRITTEN LANGUAGE SKILLS BERBASIS CURAH PENDAPAT
}

\author{
Rita Suswati, Citra Anggia Putri, Ade Aini Nuran \\ Universitas Negeri Medan \\ Email: rita.suswati@gmail.com
}

\begin{abstract}
Abstrak : Penelitian ini pada dasarnya bertujuan untuk menemukan materi pembelajaran yang tepat dalam pengajaran Written Language Skills (Reading \&Writing), dengan menggunakan teks dari media social dan metode curah pendapat. Curah pendapat merupakan tehnik penyelesaian yang bisa digunakan baik secara individual maupun kelompok, mencakup pencatatan gagasan-gagasan yang terjadi spontan dengan cara tidak menghakimi. Berdasarkan proses pembelajaran dikelas, ditemukan beberapa permasalahan yang dilakukan mahasiswa ketika menulis dan membaca: (1) mahasiswa tidak bisa mengembangkan ide ketika menulis, (2) mahasiswa bosan dengan materi yang konvensional. Ada beberapa hal yang menyebabkan hal ini; (1) bahan ajar yang tidak kekinian (2) bahan ajar yang monoton, penuh dengan nasari dan kurangnya visual gambar. Bahan ajar dikembangkan melalui review dan validasi pakar dan mahasiswa. Penelitian menunjukkan bahwa bahan ajar yang telah dikembangkan berhasil meningkatkan minat belajar dan interaksi mahasiswa sebesar $87 \%$. Tujuan akhir penelitian ini adalah untuk mengivestigasi pembelajaran written language skills dengan metode curah pendapat dengan R\&D dan menginovasi bahan ajar written language skills.
\end{abstract}

Kata kunci : social media, metode curah pendapat, bahan ajar written language skills

Membaca dan menulis merupakan keterampilan bahasa yang harus dikuasai mahasiswa. Membaca merupakan proses pemahaman dari yang kita lihat atau baca. Dengan membaca mahasiswa akan mengekstrak makna dari wacana atau teks bacaannya.(Harmer; 199).

Reading is generally perceived as the process of recognition and comprehension of written or printed materials. University students are expected to read critically to understand and connect the information in the text thoroughly as well as to help them discover knowledge from the text. Critical reading demands students to make judgments about what they read; as critical readers, therefore, they should know not only what the text says but also how the author expresses the various uniqueness of the text. When the students read critically, they should be able to evaluate, synthesize, and analyze texts which might be reflected by restating, describing, and interpreting the content of the text. Richards and Schmidt (2002, p. 134)

Untuk bisa menguasai keterampilan ini dibutuhkan bukan hanya metode tetapi juga bahan ajar yang kekinian. Bentuk bahan ajar yang kekinian beragam banyaknya. Penggunaan social media telah menjadi trend tahun 2010-an. Berdasarkan data tahunan mengenai sosial media yang digunakan pendidikan tinggi ditahun 2013 dan disurvey oleh Pearson Learning 
Solutions dan Babson Survey Research Group, penggunaan social media telah tumbuh 21\% dari tahun 2012 ke tahun 2013 di United States. Selama tiga tahun berturut-turut, respondent melaporkan peningkatan impact komunikasi digital ada hubungannya dengan komunikasi dengan mahasiswa. Persentasi penggunaan social media secara pribadi, budaya belajar dalam menulis bahasa Inggris. Untuk pengajaran meningkat menjadi 70\% dan kebutuhan pribadi menjadi $41 \%$. Wikis dan Blogs merupakan aplikasi dan web yang paling banyak diakses sepanjang tahun, sedangkan Facebook dipakai untuk kebutuhan pribadi.

Dalam pengajaran di bahasa Inggris, penggunaan social media telah berkembang sepanjang masa. Wikis, Forums atau Blogs telah banyak digunakan untuk kolaborasi menulis, memfasilitasi proses menulis, FB sebagai budaya belajar bahasa Inggris telah dikembangkan dalam penelitian, juga dalam diskusi. Penggunaan you tube juga tidak ketinggalan, merupakan kebutuhan hamper semua orang, mulai dari ank kecil hingga pengajar. Karenya pengaruh social media dalam pengajaran bahasa Inggris tidak bisa lagi diabaikan. Adapun bentuk social media yang dipilih untuk instrument penelitian terdiri dari, Instagram, FB dan Whatapps.

Penggunaan alat yang canggih juga mendukung akses social media, sehingga mahasiswa bisa belajar kapan saja dan dimana saja. Teknologi mobile telah mengarahkan orang untuk membawa sendiri laptopnya, bukan lagi dalam bentuk besar melainkan dengan handphone. Semua bisa dilakukan dalam satu tangan. Penggunaan akses mobile memudahkan mahasiswa dalam belajar didalam dan diluar ruangan.

Penggunaan mobil telah diimplementasikan diseluruh belahan dunia (Bebell \& O'Dwyer, 2010; Fleischer, 2012; Zucker \& Light, 2009), mulai dari SD hingga Universitas, bahkan berita terbaru mengatakan bahwa Tk dipedalaman Jepang telah menggunakan note sebagai papan belajarnya. Sebagai tambahan, mobile bukan hanya mensupport kegiatan belajar tetapi juga melalui social media yang digunakan bisa meningkatkan pengembangan ide menulis mahasiswa. Pengumpulan informasi data dan membaginya juga dapat meningkatkan inovasi dalam pengajaran, seperti metode cooperative learning (Lan, Sung, \& Chang, 2007; Roschelle et al., 2010), exploratory learning outside the classroom (Liu, Lin, Tsai, \& Paas, 2012), and game- based learning (Klopfer, Sheldon, Perry, \& Chen, 2012). Karenya teknologi mobile memiliki peluang yang besar untuk meningkatkan inovasi belajar, bukan hanya membantu mahasiswa tetapi juga menjalin komunikasi yang baik antar siswa dan dosen. (Warschauer, 2007). 
Perbedaaan penelitian ini dengan penelitian sebelumnya yaitu peneliti mencoba menyusun desain dan mengembangkan pembelajaran Written Language Skills berbasis curah pendapat untuk meningkatkan kreativitas dan interaksi mahasiswa pendidikan bahasa Inggris UNIMED. Dengan ini diharapkan mahasiswa bahasa Inggris mampu meningkatkan minat belajarnya.

Kajian ini sangat berguna dan layak untuk dilakukan. Hal ini disebabkan dengan diketahuinya masalah pembelajaran mahasiswa ketika belajar membaca dan kesulitan yang ditemukan dalam menjawab pertanyaan yang berkaitan dengan teks akan dapat ditemukan metode dan bahan ajar yang tepat untuk pembelajaran membaca. Hal ini diharapkan akan berdampak dalam peningkatan kreatifitas dan interkasi mahasiswa dalam PBM Written Language Skills dan mata kuliah lainnya.

Penelian ini berusaha menjawab pertanyaan: (1) Apakah ada pengaruh penggunaan social media dalam pembelajaran bahasa Inggris?, (2) Bagaimana pengembangan bahan ajar Written Language Skills berbasis social media dengan metode curah pendapat.

\section{METODE}

Penelitian ini menggunakan metode penelitian pengembangan (Research and Development). Borg dan Gall (1983: 775) mengajukan serangkaian tahap yang harus ditempuh dalam pendekatan ini, yaitu (1) penelitian pendahuluan; (2) perencanaan pengembangan produk; (3) penciptaan produk awal ; (4) pengujian lapangan awal; (5) revisi produk awal; (6) pengujian lapangan utama; (7) revisi produk operasional; (8) pengujian lapangan operasional; (9) revisi produk akhir; dan (10) desiminasi dan distribusi.

Subjek penelitian ini mahasiswa Pendidikan Bahasa Inggris Universitas Negeri Medan tahun 2016/2017 karena produk yang dikembangkan diperuntukkan

bagi mahasiswa dalam matakuliah Written Language Skills.Jumlah subjek penelitian sebagai berikut, (1) untuk penelitian pendahuluan sejumlah 40 mahasiswa; (2) untuk uji lapangan utama sejumlah 20 mahasiswa; dan (3) untuk uji lapangan operasional sejumlah 40 mahasiswa.

Pengumpulan data dilakukan untuk mengumpulkan data lapangan, data uji coba, dan data hasil uji coba. Teknik pengumpulan data dilakukan dengan wawancara, observasi, kajian pustaka, serta teknik angket. Variabel dalam penelitian ini adalah metode curah pendapat yang mendapatkan validasi dari ahli strategi pembelajaran dan pengguna, serta kesesuaian isi yang mendapatkan validasi dari ahli materi dan pengguna. 
Data yang terkumpul, (1) keputusan terhadap materi yang akan dikembangkan terlebih dahulu dari draft materi yang ada; (2) keputusan terhadap bentuk desain produk yang akan dikembangkan; (3) hasil penilaian produk yang dilakukan oleh 2 ahli (ahli metode pengajaran dan ahli materi bahan ajar) untuk melakukan penilaian produk dari apek materi, bahasa, dan media; (4) hasil penilaian produk dilakukan untuk mengetahui kelayakan produk berdasarkan dari aspek materi, bahasa, media, dan (5) uji efektivitas produk.

Teknik analisis yang dilakukan terdiri dari analisis statistik atas ujicoba produk. Teknik analisis ujicoba produk dilakukan dengan analisis statistic deskriptif yang menggambarkan kecenderungan persentase penilaian pengguna produk atas tampilan dan isi dari produk yang dikembangkan.

Disamping prosedur diatas, juga dilakukan pemilihan bahan ajar yang tepat dengan tujuan memotivasi mahasiswa lebih interaktif dan interaksi dalam pembelajaran Written Language Skills didalam kelas. Penyusunan bahan ajar ini terdiri atas beberapa sumber valid, seperti artikel di jurnal nasional terakreditasi, buku terbitan yang berkaitan dengan Reading \& Writing dan sumber-sumber lain yang dibutuhkan.

\section{HASIL DAN PEMBAHASAN}

Hasil pengembangan berupa bahan ajar yang interaktif dan eyecatching, yang terdiri atas beragam topik sesuai dengan RPS (Rencana Pembelajaran Semester) terdiri atas sembilan (9) chapter; (1) The Essay Organization, (2) How To Identify The Topic, Main Idea \& Supporting Details, (3) Understanding Graphic And Visual Aids, (4) Tones, (5) Analytical Exposition Text, (6) Hortatory Exposition Text, (7) Discussion Text, (8) News Item, (9) Critical Judgement. Masing-masing chapter akan dilengkapi dengan standar penulisan bahan ajar dikti yang terdiri atas judul per topik, tujuan pembelajaran, kompetensi dasar, indikator pembelajaran, materi, tugas dan rangkuman dari tiap bab.

Pembelajaran Written Language Skills dengan menggunakan materi ajar yang menarik dan beragam visual aids meningkatkan kreativitas mahasiswa dalam mengembangkan ide menulis, dibandingkandengan hasil pembelajaran sebelumnya yang kurang menarik dan padat narasi. Bisa disimpulkan bahwa desain dan pengembangan materi ajar yang innovatif mampu meningkatkan minat belajar mahasiswa dalam mata kuliah Written Language Skills.

\section{Kebermaknaan Isi Produk}


Produk ini memiliki isi yang bermakna karena konten yang akan diajarkan sesuai dengan silabus, RPS dan kebutuhan minat dan kompetensi mahasiswa DIK tahun 2016/2017 yang akan mempelajari written language skills (reading \& writing).

Berdasarkan silabus KKNI pembelajaran written skill terdiri dari mata kuliah reading dan writing. Diawali dengan lliteral reading, written language skills, contextual written language skills. Masing-masing tahapan ini memiliki tujuan pengajaran dan kompetensi serta genre yang harus dicapai mahasiswa.

Konten yang tepat dari bahan ajar ini tidak terlepas dari saran para tim ahli yang mencermati produk dari materi ajar. Evaluasi ahli materi dari aspek substansi bertujuan untuk mendapatkan berbagai masukan dari segi kesesuaian produk dengan pengguna, sasaran dan kurikulum, kelengkapan dan kekayaan content (isi) produk, kejelasan deskripsi, dan kejelasan menguraikan konsep written language skills..

Ahli materi melakukan evaluasi produk dengan mencermati produk dan memberikan penilaian, saran perbaikan dan mengambil keputusan apakah produk dapat diujicoba atau tidak. Hasil evaluasi materi dari pakar materi secara umum memberikan penilaian "ya" dan "tidak ada" saran perbaikan berdasarkan indikator penilaian.

Kebermaknaan produk juga tidak terlepas dari pemilihan diksi, latihan, metode pengajaran dan referensi yang digunakan sebagai bahan ajar written language skills.

Hasil evaluasi yang didapat dari mahasiswa menunjukkan bahwa mahasiswa lebih tertarik dan ingin mempelajari topik selanjutnya dengan bahan ajar dan metode pengajaran curah pendapat.

\section{Keefektifan Rancangan Pembelajaran}

Rancangan pembelajaran ini sangat efektif karena tiap bab terdiri dari empat bagian penting, (1) awal bab menjelaskan tentang tujuan pembelajaran, kompetensi dasar, indikator pembelajaran. (2) materi bahan ajar yang akan dikembangan secara interaktif dan eyecatching, berikut tugas atau assessment yang berkaitan dengan tujuan pembelajaran (3) metode pembelajaran. 
Pertama, tujuan pembelajaran. Produk ini memiliki tujuan pembelajaran yang berada pada bagian awal dari masing-masing bab. Tujuan pembelajaran yang tertulis dalam produk pembelajaran ini berfungsi sebagai alat ukur capaian yang dilakukan mahasiswa setelah selesai pembelajaran. Apakah tujuan pembelajaran tercapai atau tidak. Sedangkan indikator dan kompetensi dasar juga perlu diletakkan di awal untuk memudahkan mahasiswa memahami apa yang harus dilakukan dan apa yang akan dicapai setelah pembelajaran selesai

Tujuan pembelajaran bisa dilihat di awal bab untuk memudahkan mahasiswa memahami keterampilan apa yang akan dicapai dari tiap bab, berikut kompetensi dasar dan indikator capainnya.

Kedua, materi bahan ajar yang akan dikembangkan terdiri atas beragam topik dan latihan yang sesuai dengan silabus dan RPS mata kuliah written language skills. Sebelum disusun menjadi bahan ajar. Pertama desain bahan ajar dipilih dari beragam sumber, diujikan kepada mahasiswa melalui pre-test, questionnaire dan wawancara, lalu dilakukan revisi awal atas produk, dilanjutkan dengan validasi oleh para pakar, dilanjutkan dengan revisi kembali sebelum disusun menjadi bahan ajar yang valid. Berikut contoh materi bahan ajar yang digunakan.

\subsection{MATERIAL}

\subsubsection{HOW TO IDENTIFY THE TOPICS, MAIN IDEA AND SUPPORTING DETAILS}

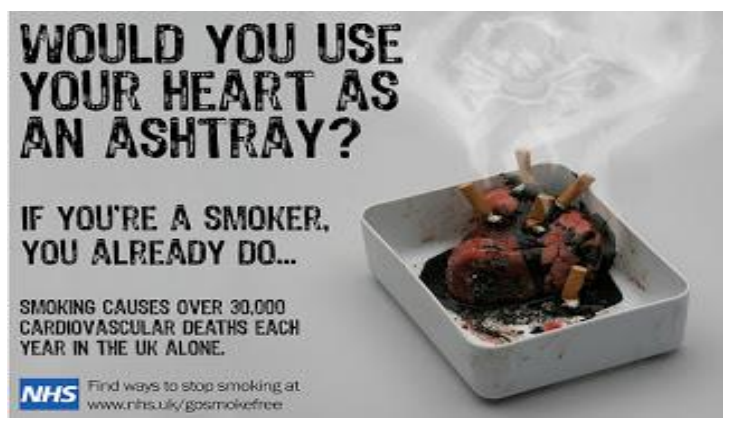

https://www.google.com/ anti+smoking+adverts+by+NHS. diakses 8 Agustus 2017

Topic : HOW TO FIND TOPIC, MAIN IDEA AND SUPPORTING DETAILS

\subsection{EVALUATION}

Assessment I. Group Discussion: What can you tell about these advertisements? (topic, main idea, supporting detail)

Tugas : Melakukan diskusi kelompok tentang topic, main idea dan supporting details. Masingmasing kelompok diberikan waktu 30 menit, setelah itu tiap kelompok memilih satu orang 
untuk memaparkan hasil diskusinya didalam kelompok dan kelompok lain bisa memberikan saran sesudahnya.

Ketiga, metode pembelajaran yang digunakan adalah metode curah pendapat. Metode curah pendapat merupakan merupakan tehnik penyelesaian yang bisa digunakan baik secara individual maupun kelompok, mencakup pencatatan gagasan-gagasan yang terjadi spontan dengan cara tidak menghakimi, (De Porter, 310). Untuk memulai pembelajaran dengan cara ini bisa dilakukan dengan tahapan berikut: (1)Sediakan kertas kosong ditiap kelompok, (2) Identifikasi masalah, (3) Tuliskan kata kunci ditengah kertas dan lingkari, (4) Catat, lingkari, hubungan semua gagasan yang ada, dengan kata kunci yang ada di tengah.

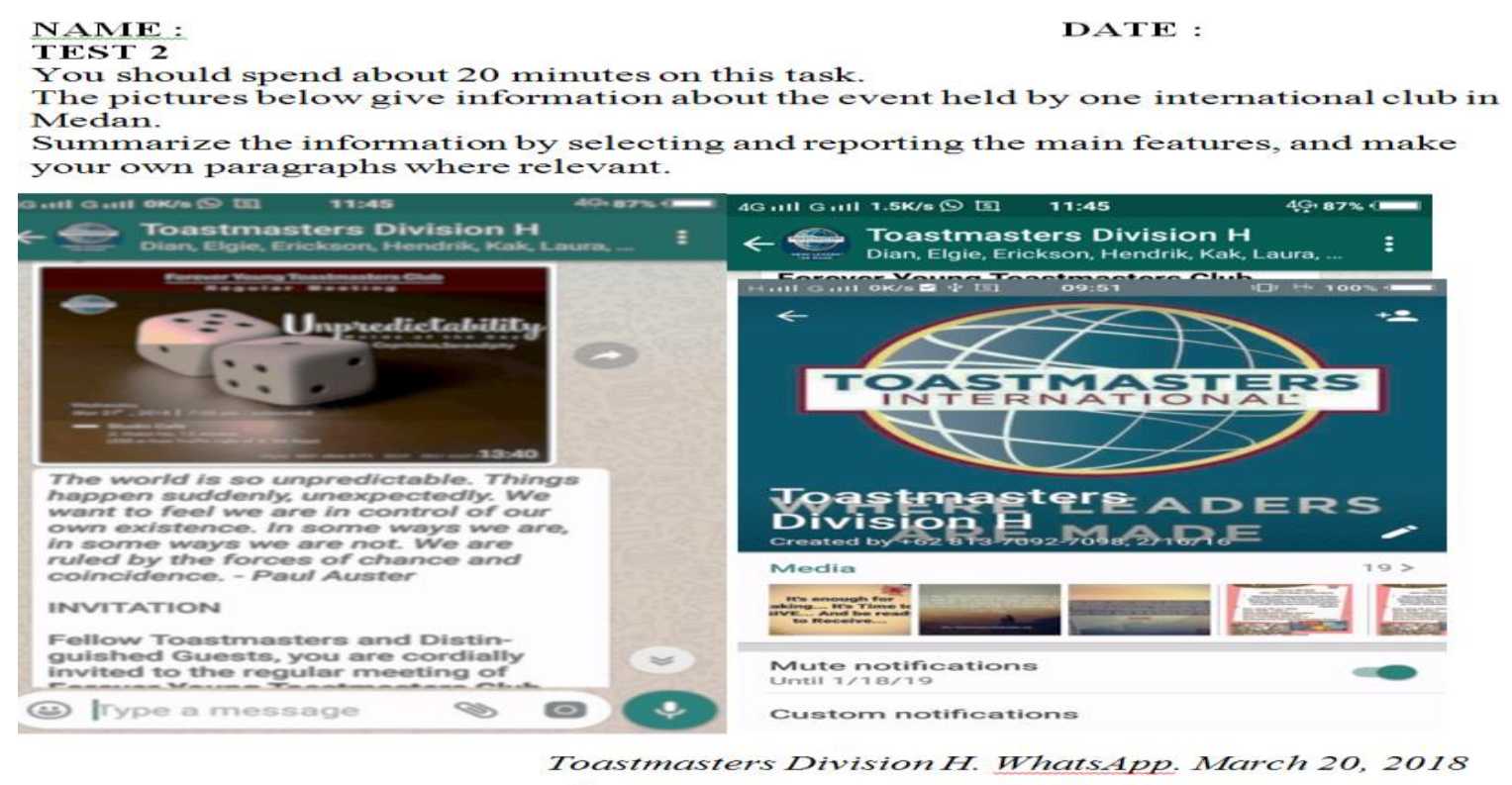

\section{Masalah Yang Dihadapi Mahasiswa Ketika Membaca}

Berdasarkan observasi dan pengambilan data yang telah dilakukan, peneliti dapat menemukan masalah yang dihadapi mahasiswa ketika membaca. Masalah ini terbagi atas dua masalah utama: (1) bahan ajar yang tidak kekinian, (2) metode pengajaran yang konvernsional/bersifat satu arah (ceramah), pendistribusian tugas yang kurang tepat dan penyusunan tata letak kelas yang tidak sesuai dengan tema yang diajarkan.

Adapun masalah lain yang ditemukan dalam penelitian ini tingkat kemampuan mahasiswa yang beragam menyulitkan mahasiswa mengikuti tema pengajaran dan tugas yang diberikan. Masalah yang timbul bisa diatasi dengan mengikuti teori dan tahapan pengajaran dengan metode curah pendapat yang dipaparkan De Porter, sebagai berikut : (1) curah pendapat 
sangat tepat untuk pengajaran kelas besar karena mahasiswa dibagi dalam kelompk kecil yang terdiri dari 5-7 mahasiswa/kelompok. Masing-masing kelompok terdiri dari mahasiswa yang terampil, kurang terampil dan pemula. Masing-masing individu dalam kelompoknya berhak mencurahkan pendapatnya tanpa merasa dihakimi apakah pendapatnya benar atau salah, (2) desain dan pengembangan bahan ajar yang colourful dan eyecatching mampu menimbulkan kreatifitas dan interaksi mahasiswa dikelas.

Dari penjelasan diatas dapat disimpulkan bahwa curah pendapat adalah metode pembelajaran yang dapat digunakan untuk belajar bahasa asing (bahasa inggris) dengan menghubungan gagagasan-gagasan mahasiswa dalam menyelesaikan suatu masalah dan mampu menghasilkan rancangan bahan ajar dan yang tepat untuk mata kuliah written language skills.

\section{Ketepatan Teknologi}

Ketetepatan teknologi yang dipakai dipaparkan sebagai berikut. Pertama, Produk ini fokus pada bahan ajar yang interaktif dan eyecatching serta kemudahannya yang membantu konten dan desain pembelajaran dapat dipahami para pengguna. Salah satu karakteristik kunci dari pembelajaran written language skills berbasis curah pendapat melibatkan interaksi mahasiswa dan dosen dalam tahapan pengajarannya dengan beragam visual aids yang ditampilkan. Kedua, produk ini dipilih dan didesain secara bertahap, melalui serangkaian test dan revisi sehingga pengembangan bahan ajar ini masih membutuhkan saran dan masukan yang membangun.Produk ini sudah diperbaiki berdasarkan saran

perbaikan para pakar pengembangan dan bahan ajar reading dan writing. Hasil ujicoba lapangan terhadap peningkatan minat belajar mahasiswa, khususnya written language skills meningkat.

\section{SIMPULAN}

Hasil pengembangan desain pembelajaran dengan metode curah gagasan menunjukkan bahwa keterampilan membaca dan menulis mahasiswa pendidikan bahasa Inggris bisa meningkat dengan melaksanakan tahapan pengajaran dengan metode curah pendapat secara berurutan.

Berdasarkan hasil analisis ditemukan bahwa pembelajaran dengan bahan social media dan metode curah pendapat dikelas pendidikan bahasa Inggris mampu mengatasi masalah mahasiswa selama ini yaitu kurang kreatif dan interaksi didalam kelas. 
Pengembangan bahan ajar yang colourful dan eyecatching juga mampu meningkatkan minat belajar mahasiswa untuk terus membaca dan menjawab tugas yang diberikan hingga $87 \%$.

Penggunaan bahan ajar yang efektif, sesuai dengan kurikulum dan kebutuhan mahasiswa bisa mengatasi masalah minat belajar mahasiswa dikelas dan meningkatkan hasil belajar mahasiswa, khususnya mahasiswa yang mengambil mata kuliah Written Language Skills dan memudahkan dosen pengampu dalam menjalankan SCL (Student Center Learning).

\section{DAFTAR RUJUKAN}

Buzan, Tony.2004. Mind Map untuk Meningkatkan Kreatifitas. Jakarta. PT. Gramedia Pustaka Utama.

De Porter, Bobbi \& Hernacki, Mike. 2010. Quantum Learning, Membiasakan Belajar Nyaman dan Menyenangkan. Mizan Medai Utama. Jakarta

Harmer, Jeremy. 2003. English Language Teaching. Cambridge.

J. Seaman, H. Tinti-Kane, and L. Solutions, Babson Survey Research Group, Social Media for Teaching and Learning, Pearson Learning Systems UK, 2013. istepi

Noor, , Khumaidi. (2013) The Use of Brainstorming to Improve Students' Writing Skill in Descriptive Text (A Classroom Action Research of The Tenth Grade Students of SMA 2 BAE Kudus in the Academic Year 2012/2013). Skripsi Sarjana thesis, Universitas Muria Kudus.

Puskur. Pengembangan dan Pendidikan Budaya \& Karakter Bangsa: Pedoman Sekolah. 2009:9-10.

Richards, J. C., \& Schmidt, R. (2002). Longman dictionary of language teaching and applied linguistics ( ${ }^{\text {rd }}$ Ed.). London: Pearson Education.

Suswati, Rita. 2011. Implikasi Penerapan Quantum Learning untuk Meningkatkan Reading Skill Mahasiswa Bahasa Inggris UNIMED. Lemlit UNIMED.

Sugiyono. (2007). Metode Penilaian Pendidikan (Pendekatan Kuantitatif, Kualitatif dan R/D). Bandung: Alfabeta.

Harmer, Jeremy. 2003. English Language Teaching. Cambridge.

Noor, , Khumaidi. (2013) The Use of Brainstorming to Improve Students' Writing Skill in Descriptive Text (A Classroom Action Research of The Tenth Grade Students of SMA 2 BAE Kudus in the Academic Year 2012/2013). Skripsi Sarjana thesis, Universitas Muria Kudus.

Suswati, Rita. 2011. Implikasi Penerapan Quantum Learning untuk Meningkatkan Reading Skill Mahasiswa Bahasa Inggris UNIMED. Lemlit UNIMED.

Sugiyono. (2007). Metode Penilaian Pendidikan (Pendekatan Kuantitatif, Kualitatif dan R/D). Bandung: Alfabeta.

Warschauer, M. (2007). A teacher's place in the digital divide. Yearbook of the National Society for the Study of Education, 106, 147e166. http://dx.doi.org/10. 1111/j.17447984.2007.00118.x.

Warschauer, M., Zheng, B., Niiya, M., Cotten, S., \& Farkas, G. (2014). Balancing the one-toone equation: equity and access in three laptop programs. Equity \& Excellence in Education, 47, 46e6http://dx.doi.org/10.1080/10665684.2014.866871.s'spi.

https://www.google.com/ anti+smoking +adverts $+b y+N H S$. diakses 8 Agustus 2017 
http://www.gambarkatalucu.co/contoh-cv-yang-menarik-dalam-bentuk-word-contoh-cvkreatif-contoh-cv/diakses 8 Agustus, 2017

http://dx.doi.org/10.1016/j.compedu.2015.11.008 Published by Elsevier Ltd. This is an open access article under the CC BY-NC-ND license (http://creativecommons.org/ licenses/by-nc-nd/4.0/).

https://www.google.com/ anti+smoking +adverts $+b y+N H S$. diakses 8 Agustus 2017 http://www.gambarkatalucu.co/contoh-cv-yang-menarik-dalam-bentuk-word-contoh-cvkreatif-contoh-cv/diakses 8 Agustus, 2017 